\title{
Visual ethnography for performative geographies: how women politicians perform identities on Ecuadorian political stages
}

\author{
C. Schurr \\ Department of Geography, Graduate School of the Interdisciplinary Centre \\ for Gender Studies (IZFG), Bern, Switzerland \\ Correspondence to: C. Schurr (schurr@giub.unibe.ch)
}

\begin{abstract}
While there has been intense discussion of the theories of performativity in human geography, little has been said about the methodological implications of the performative turn. This paper suggests visual ethnography as a suitable methodology for performative geographies, since it focuses explicitly on the embodied and non-textual performances that bring both subjectivities and spatialities into being. In order to be able to connect the observed performances with performativity, a visual ethnography of performativity needs to be developed that combines visual research methods with insights about visual culture. By drawing on a visual ethnographic case study of politicians' identity performances in Ecuador, I show in the empirical section of this paper how the filmed identity performances can be linked and contrasted to hegemonic discourses around masculinity, femininity, whiteness, and indigenousness represented in Ecuador's visual culture. This visual ethnography reveals the ambivalence of their identity performances in which the politicians are constantly torn between responding to and simultaneously resisting hegemonic discourses around the masculinity and whiteness of the political.
\end{abstract}

\section{1}

\section{Opening credits}

(see Video 1: Pachakutik's electoral march, http://youtu.be/KNflPx3ZsHs)

I am standing on the sidewalk of the central boulevard of the Amazonian town Francisco de Orellana, called by most inhabitants only "Coca", filming "my women" in the electoral march they have organised to close the electoral campaign of the indigenous and campesino party Pachakutik. Mayor Anita Rivas heads the march, energetically shouting the electoral chants (Fig. 1); Emma, a candidate for the town council, waves to me when she spots me (Fig. 2) and many women follow with flags and banners to support their candidates (Fig. 3). When I say "my women" I do not want to sound possessive, but to express the emotional bond I have developed with the female politicians and candidates of the party Pachakutik in Coca over the time I have spent interviewing and accom- panying them in their everyday political activities. Hence, while filming the march on behalf of Anita Rivas, I am as euphoric as they are about the mass of people who have joined the march and the joyful atmosphere that the rainbow-coloured Pachakutik flags and the chants produce.

What does this short visual ethnographic narrative tell about the geographies of local politics in Ecuador? What first catches our visual attention is the rainbow colour of the indigenous whipala flag. The omnipresence of the flag's rainbow colours, so central for the constitution of this temporary political spatiality of the campaign, can be seen as a visual marker of the indigenous movement's political empowerment process. Hence, the whipala flag stands in as a symbol of the indigenous movement's long struggles to acquire political voice and access to spaces of politics ${ }^{1}$ from

\footnotetext{
${ }^{1}$ I adopt here Mouffe's (2005:8-9) useful distinction between the political and politics by differentiating between political spaces and spaces of politics. Following Mouffe, I understand political spaces
} 


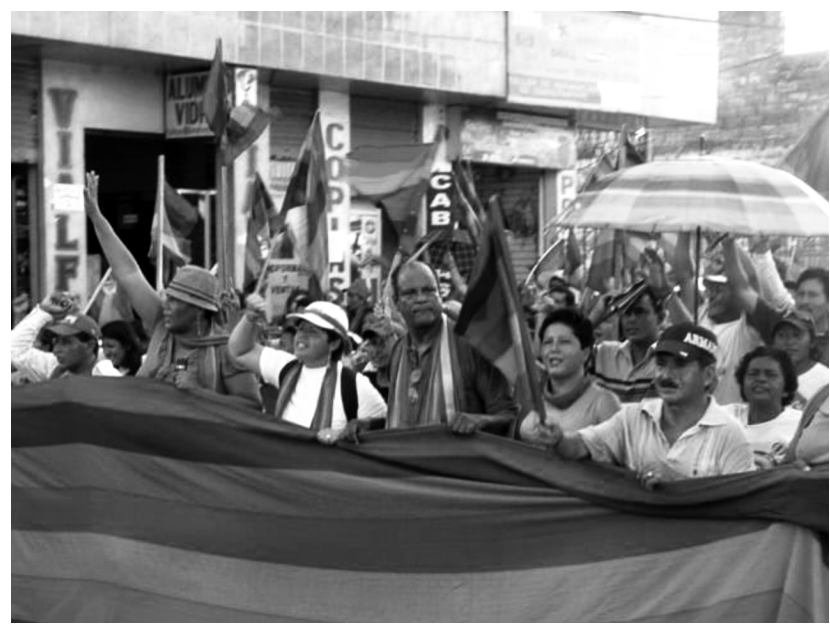

Figure 1. Electoral march.

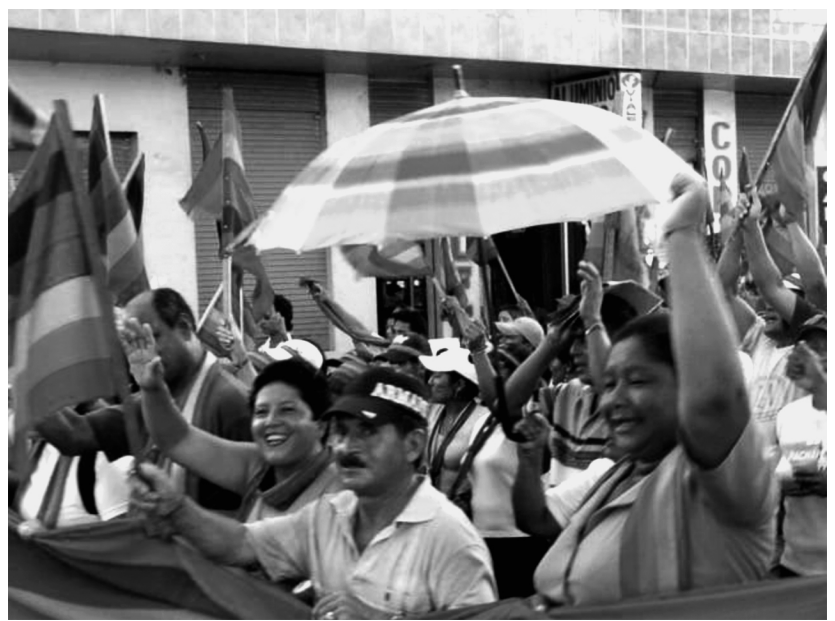

Figure 2. Emma waving.

which indigenous people were de facto excluded until the 1980s. What draws attention at a second glance is that the march is headed by a woman, Mayor Anita Rivas who is running for re-election and is surrounded by the other candidates of Pachakutik. The strong presence of women in this local political event is directly linked to the long struggle of women's organizations which culminated in a gender-quota law in the Constitution of 1998 . Hence, the visual narrative reflects recent political transformations regarding the way the local spaces of politics are gendered and ethnicised.

as the spatial materialisation of antagonism inherent in all human society. Hence, a political space is any space which is brought into being through the antagonistic relation between hegemonic and counter-hegemonic subjectivities. In contrast, spaces of politics are the outcome of a "set of practices and institutions through which an order is created" (Mouffe, 2005:9). In democratic societies, these spaces of politics include the juridical, executive and legislative institutions that constitute the pillars of any democracy.

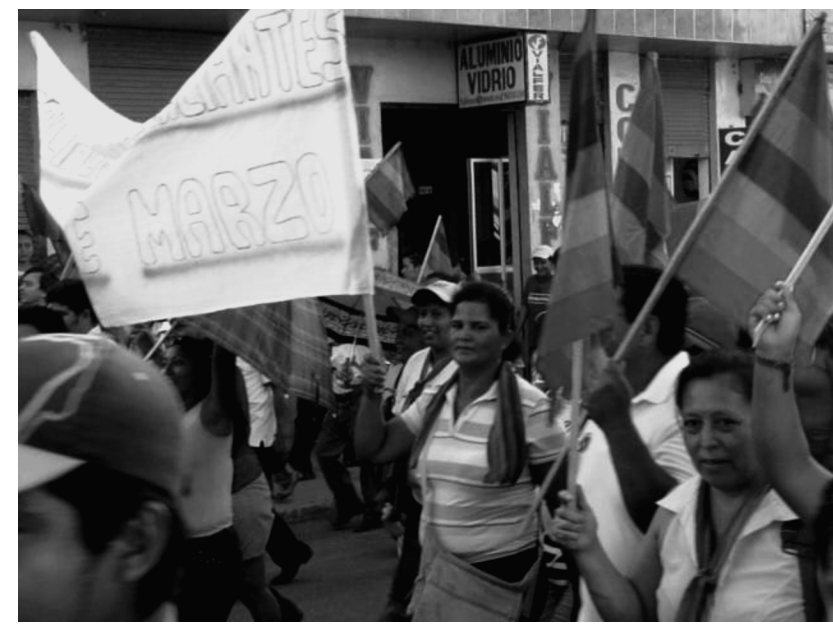

Figure 3. Constituents.

This introductory visual narrative on the one hand aims to present the central issues of my research about current political transformation processes with regard to women's and indigenous people's electoral participation. On the other hand, it serves to show that visual methodologies constitute a fruitful tool "to capture and foreground the processes of [...] change" (Spencer, 2011:34). This visual narrative highlights that spaces of politics are not only brought into being through language but also through a number of non-textual practices such as walking, smiling, clapping and symbols such as the Pachakutik flag. Hence, when researching processes of change and their spatial materialisation, the focus needs to be on both the linguistic performances and on the non-textual practices that constitute the very processes of change. "Performative geographies" is the term for the research perspective that brings linguistic and embodied performances together. I argue here that visual ethnography is an especially suitable methodology for capturing these performances that are central to performative geographies.

\section{Genre: visualising the performative turn}

At the beginning of the millennium, Nash (2000:654) identified a "metaphorical and substantive turn from 'text' and representations, to performance and practices" in human geography. The "performative geographies" that result from this turn criticise poststructuralist geographies for remaining "strongly focused on the verbal" (Crang, 2002:652) and call for a stronger focus on the embodiment of everyday practices and the cardinal role of the body within these practices. The concept of performativity, as developed by Butler (1990), offers a possibility to combine the performances and practices - the "acting out" - with the enabling and disciplining effects of discourse.

Butler (1990) has shown that one's gender identity is neither solely located in bodily difference nor is it the result 
of a free-floating choice. Rather, women and men learn to perform the sedimented forms of gendered social practices that become so routinised as to appear natural. Gender does not exist outside its "doing", its performance, but this performance is also a reiteration of previous "doings" that become naturalised as gender norms. In an attempt to integrate Butler's thinking into human geography, Gregson and Rose (2000:434) have argued that "space too needs to be thought of as brought into being through performances and as a performative articulation of power".

There are vibrant discussions in human geography as to how to methodologically redeem the theoretical ambition of performative geographies (Dirksmeier and Helbrecht, 2008; Latham, 2003; Morton, 2005). Visual methodologies are considered a fruitful way out of the "textual trap" (Lorimer, 2010:242), as they permit a focus on embodied practices which escape text- and talk-based approaches. Both anthropology and human geography have a long tradition of using photographs, diagrams, maps and film. Rose (2011:10), however, points out that a proliferation of visual methodologies has occurred only in recent times within and beyond these disciplines (El Guindi, 2004; Emmison and Smith, 2000; Garrett, 2011; Pink, 2001; Rose, 2011; Spencer, 2011; Sturken and Cartwright, 2009). Human geographers have increasingly incorporated visual methods such as video (Garrett, 2011; Kindon, 2003; Simpson, 2011) or photography (Latham, 2003) in their research in an attempt to pay greater attention "to the corporeal aspects of knowledge production by focusing on [...] body language, use of and movements through space" (Kindon, 2003:147). For Garrett (2011:12), "there is a great deal that cannot be written or spoken that can be expressed through performance, gesture and polysemous representation on film". Hence, the strength of visual methods consists of capturing non-linguistic performances that have gained importance in the theoretical concerns of performative geographies.

While the increasing use of visual methods in human geography can be seen as one methodological response to the performative turn, Herbert's (2000) "call for ethnography" can be considered another attempt to enrich the methodological toolkit of human geography with methodologies that are suitable to "explore the [non-linguistic] tissue of everyday life" (Herbert, 2000:551). His request "for [more] ethnography" in human geography has gained increasing support (Kofman, 2008; Megoran, 2006). Especially as a consequence of the turn from texts and representations to performances and practices (Nash, 2000:654), geographers have recognised that ethnography "provides singular insights into the processes and meanings that undergird socio-spatial life" (Herbert, 2000:550). Megoran (2006) highlights that these particular insights are possible due to the epistemological distinction between ethnographic and social science research. For Verne (also in this issue), this epistemological distinction is grounded in Geertz's (1973:6) understanding of ethnography as an "intellectual effort" and not the mere use of certain techniques. The "intellectual effort" of doing ethnography consists of "trying to read (in the sense of "construct a reading of") a manuscript - foreign, faded, full of ellipses, incoherencies, suspicious emendations, and tendentious commentaries" (Geertz, 1973:10). In order to be able to "construct a reading of" this foreign, unfamiliar manuscript, a long-term engagement and close observation of the researched context is necessary. It is important to highlight here that ethnography as a research methodology is inherently visual, as it focuses on practices of looking and observing. While the "visual in ethnographic research has generally not been used intrinsically for interpreting and representing ethnographic data" (O'Neill et al., 2002:72) but as merely illustrative, visual ethnography makes the visual aspect of ethnography explicit by giving the visual data a more analytic treatment.

Although visual and ethnographic methodologies have received increased attention in human geography, empirical work that brings both methodological approaches together in the form of visual ethnography is still scarce. Byron's (1993) study about post-war migration in the Eastern Caribbean is an early example of geographers integrating video in their ethnographic research. More recently, Kindon (2003:142), who, during her ethnographic fieldwork, conducted a participatory video project with members of a Maaori tribe in Aotearoa, New Zealand, advocates the use of participatory video making as a feminist methodology that provides a "practice of look 'alongside' rather than 'at' research subjects". In a similar vein, Young and Barrett (2001) highlight the effectiveness of using visual "action" methods to encourage child-led activities in their research with street children in Kampala, Uganda.

I argue here that human geography can benefit beyond this participative aspect from anthropology's experiences with visual ethnographies (Collier and Collier, 1986; Mead, 2003; Pink, 2001) when linking visual ethnographic methods to current theoretical discussions about performativity and performance in human geography (Gregson and Rose, 2000). Visual ethnography offers a unique possibility to connect observed performances to performativity - the discursive framing that disciplines and enables these performances. To bring together the study of performance and performativity, a visual ethnography needs to be developed that combines visual research methods with insights gained from studies of visual culture (as suggested by Rose, 2011). In the following, I develop what I call a "visual ethnography of performativity" that explicitly connects observed performances with performativity - the "citational practices" (Butler, 1993:108) that enable and discipline subjects and their performances. Hence, such a visual ethnography of performativity focuses on the relation between subjective performances and hegemonic discourses in which these performances are embedded. Pink (2008) suggests a "media ethnography", the close examination of visual representations in media, as a way to engage with hegemonic visual representations within certain 
cultural contexts. By linking self-produced visual data with visual data produced by the media, it is possible for the researcher to relate, compare and contrast his or her own visual data with hegemonic visual representations of certain performances.

Drawing on my visual ethnography of politicians' identity performances in Ecuador, I will show in the empirical section of this paper how the filmed identity performances can be linked and contrasted to hegemonic discourses around masculinity, femininity, whiteness, and indigenousness represented in Ecuador's visual culture. Before doing so, I would like to reflect on the way the video camera became not only a research device but an active agent that enacted reality within my research process in a particular way (Law and Urry, 2004).

\section{Stage direction: struggling with the camera in ethnographic fieldwork}

In this section, I outline my methodological approach and reflect critically on the research process and related ethical concerns. It is worth highlighting that originally the research project did not include visual methods. Identity and spatial constructions within local politics were "intended" to be captured during extensive ethnographic fieldwork in three municipalities mainly through interviews and (participant) observation. At the beginning, I was reluctant to use video or photography. Postcolonial critiques (Said, 1978) about the way the East became orientalised by the West through images weighed heavily on my (post)colonial academic consciousness. My firm ethical conviction was rocked when during my first field trip I accompanied a mayor and a television cameraman to a political meeting. Watching the mayor preparing herself for her performance by putting on make-up and tidying up her clothes, I felt that a camera might even trigger what I was looking for: the (un)conscious performance of gendered, ethnic, classed and political identity. I returned for my second field trip to the same women with a digital camera and video camcorder and asked timidly for permission to photograph and videotape their daily activities. I was overwhelmed about how euphoric every single woman was about the idea and all of them asked me to allow them to use the recordings later for their own purpose. From that moment on, I was given a new role: I became their personal camerawoman and was constantly asked to accompany them to meetings, audiences and gatherings. At last - in my view and probably also in the view of my research partners - I had a reason to be around the politicians all the time. The up-coming electoral campaign literally turned out to be the ideal stage to research the politicians' performances. Alongside local media people, I recorded political speeches, electoral demonstrations and house-to-house campaigns.

During my research process, the camera functioned as a kind of "can-opener" as described by Collier and Col- lier (1986): first, playing the camerawoman put me in an ideal position to observe the women I was researching and gave me legitimacy to do so. Second, when I showed the videos and photographs to the politicians, fruitful discussions took place about the course of the event, their feelings during the event and reflections about their performances. Even though I had lived in Ecuador for a long time and had worked with local politicians on various occasions, my own position as a middle-class European researcher often "directed my gaze" in an Eurocentric way to certain aspects (often the "exotic") that did not attract the attention of the research participants (e.g. indigenous symbols such as the Shigra bag) and that at the same time overlooked other aspects (e.g. small gestures between the candidates that they directly interpreted as signs of friendship or conflict). The constant discussion about the videos and photos with research participants and later on with Ecuadorian colleagues was crucial for me. I could thus challenge my biased interpretation of the visual data and avoid the risk of producing interpretations that exoticised or stereotyped those I was researching (Spencer, 2011:489).

In hindsight, I think it is important to acknowledge both the added value and the challenges of using a camera in ethnographic research. Pink (2001:98) reminds us that the "reflexive use of video in ethnography means using video not simply to record data, but as a medium through which ethnographic knowledge is created". Within my research process, the camera was used to collect data to then illustrate my textbased arguments; but more importantly, it played an active role in producing the data - both in its visual forms, when the camera provoked certain performances from research participants, but also in textual forms, through the discussions when I watched the visual data with research participants. Further, the "media ethnography" (Pink, 2008) I conducted by analyzing local and national newspaper articles, television programs and electoral propaganda facilitated embedding my own filming and the analysis of my visual data in the visual culture of Ecuadorian politics.

Nevertheless, during the whole research process, the awareness of visual anthropology's colonial roots frequently made videotaping a contested endeavour for me when confronted with ethical questions about whom and when to film, when feeling power relations between myself and those filmed due to the material value and social status of my camera and finally when wondering whether my own position complicated and biased the filming (Kindon, 2003). On many occasions, I decided not to film and preferred to silently observe what was going on. I often decided spontaneously and intuitively when and where to film. I would also often check with some women politicians I had already established rapport with as to whether it was appropriate to film. In general, it was less problematic to film the politicians themselves, as they are used to being at the centre of media interest, than to film farmers or indigenous people who are rarely faced with a camera. 


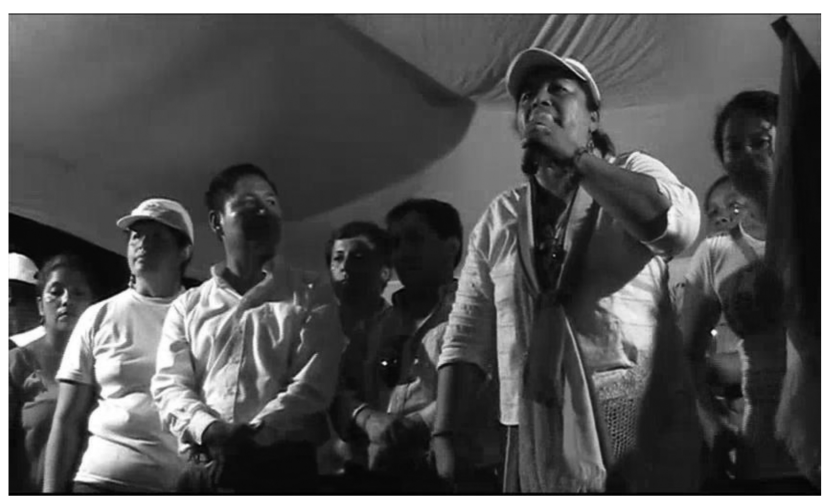

Figure 4. Guadalupe Llori on the stage.

\section{On the set: women politicians' performances on the political stage}

What do we see, then, when we look through the camera at women politicians' identity performances from a performative perspective? Looking at the case of Guadalupe Llori, Prefect of the Amazon Province Orellana, I demonstrate how the concept of identity can be examined through the lens of visual ethnography. I also analyse her performances during the final campaign day in order to discuss the way her performance is embedded in (and at the same time challenges) hegemonic imaginaries of the political that are (post)colonially gendered and racialised as masculine and white. Although much more could be said, I will restrict my analysis to the three central analytical categories in my research project: political identity, ethnicity, and gender.

During the observed campaign event, Guadalupe Llori is staged in the middle of the scene, which emphasises her central political position within the indigenous party Pachakutik (Fig. 4). She is wearing light casual trousers, sandals, a yellow farmer's shirt and a baseball cap. She is outfitted with accessories in the rainbow colors of Pachakutik, which resemble the Incan Wipala flag. An indigenous handbag, the shigra, is slung over her shoulder.

What does the way Guadalupe is dressed tell about her political identity? While all candidates wear small accessories in rainbow colours, Guadalupe is covered from head to toe with these accessories, including earrings, bracelet, scarves and a ribbon around her baseball cap. This attire she has chosen allows the people to understand that she is the real and only representative of the Pachakutik movement. By wearing quite casual clothes, including the shigra handbag, she positions herself close to the people, her people and her community. While traditionally white-mestizo male politicians are dressed rather formally in business suits, more and more politicians of the left have replaced their formal clothes with a more casual look.

Not only through her dress, but also through her political rhetoric, Guadalupe performs her political identity, when, for example, in the first few minutes of her speech she emphasises (video 2: campaign speech Guadalupe Llori, http: //youtu.be/KNflPx3ZsHs) that "we must not divide the people (pueblos), we must not divide the indigenous nationalities (nacionalidades), we must stay together and fight for balance (equilibrio), equality (equidad), compañeros" (political speech, 21 April 2009, own translation). Without elaborating her ideas as to how this balance and equity should be achieved, she picks up a rhetoric found in the national indigenous organization (CONAIE) and a world view celebrated by indigenous leaders. She states in an interview: "Because I have identified since childhood with my indigenous brothers and have incorporated their ideological principles and moral values, I chose to join Pachakutik in order to fight for the impoverished mass of my people" (interview Llori, 17 February 2010, own translation).

While the performance observed so far might suggest that she is performing an indigenous ethnic identity, in fact she does not have biographical roots in an indigenous community. She compensates her inability to speak kichwa, the indigenous language, by decorating herself all over with indigenous symbols and by emphasizing in her speech her political proximity with indigenous values. Within the province of Orellana, people picture her as a typical mestiza who supports the cause of the indigenous people. Guadalupe Llori herself, however, appropriates different ethnic performances according to the audience and the message she wants to deliver. The video from the Human Rights Foundation Forum where she was honoured for her fight against petroleum activities in the province shows that in the video she refers to herself as indigenous (video 3: Guadalupe Llori at the Oslo Freedom Forum, http://youtu.be/KNflPx3ZsHs). Her campaign poster (Fig. 5), however, represents her in a hybrid mixture of a white upper-class woman - emphasised by her blonde-highlighted hair and her make-up - and an indigenous identity expressed through the rainbow coloured earrings and scarf. This image might be interpreted as an attempt to respond to discursive hegemonic imaginations of a politician as white, well-educated, and upper-class and to establish a close relationship to the "simple" poor and indigenous people at the same time. Hence, Guadalupe's performance reveals an ambivalent and hybrid ethnicised political identity.

What can be said about Guadalupe Llori's performance of gender identity when contrasting the visual recordings of her electoral speech with this election poster? While the election poster emphasises her femininity through the earrings, make-up, lipstick, and well-coiffed hair, her embodied performance on the political stage, including her clothing, body movements and the tone of her voice, enacts a rather masculine performance. Listening to her campaign and watching her body language reminded me of other socialist (male) political leaders such as Hugo Chavez, Fidel Castro or Che Guevara. Her affinity to these men becomes evident by wearing a wristlet with the icon of Che Guevara or by using a similar rhetoric such as "hasta la victoria siempre". By doing 


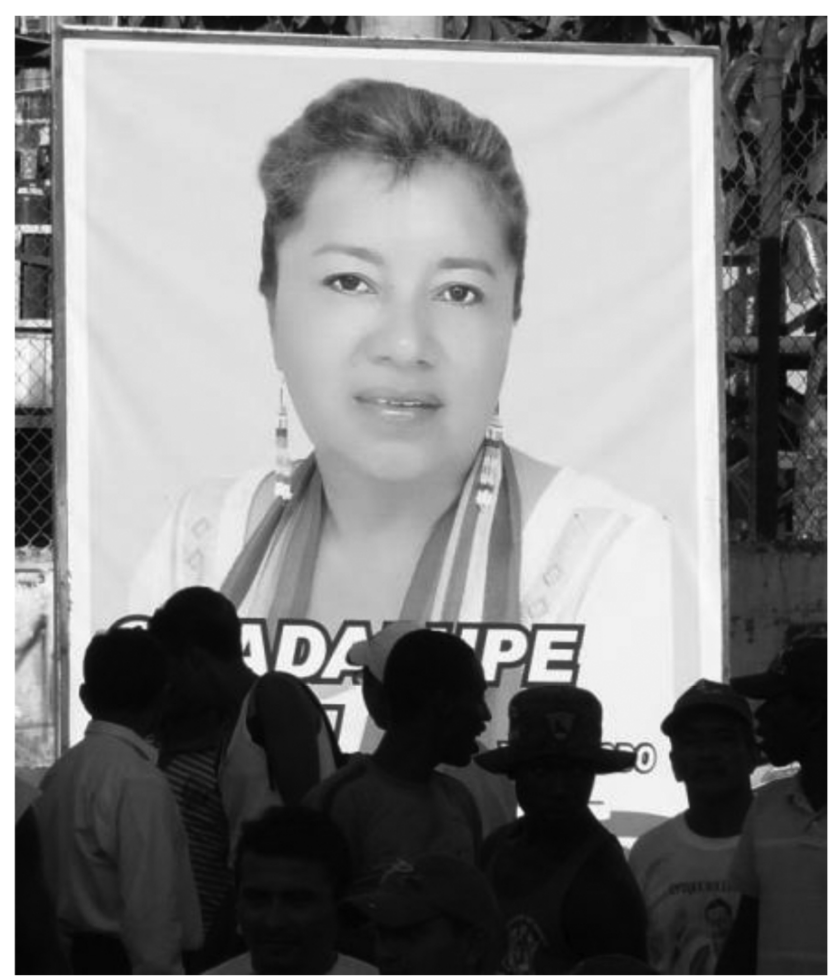

Figure 5. Guadalupe Llori's campaign poster.

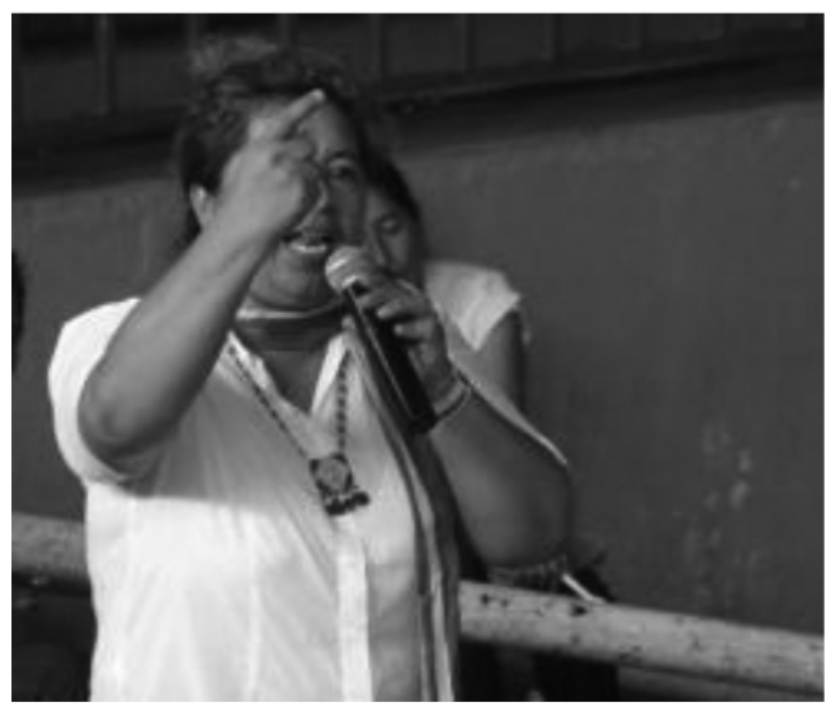

Figure 6. Guadalupe Llori.

so, she embeds her own identity performances within socialist imaginaries of politics that dominate contemporary Latin American (left-wing) politics (Castañeda, 2006). Her body language and way of speaking copy the performances of her male idols when she shouts energetically or raises her left index finger (Fig. 6) like Che Guevara (Fig. 7) or Fidel Castro (Fig. 8).

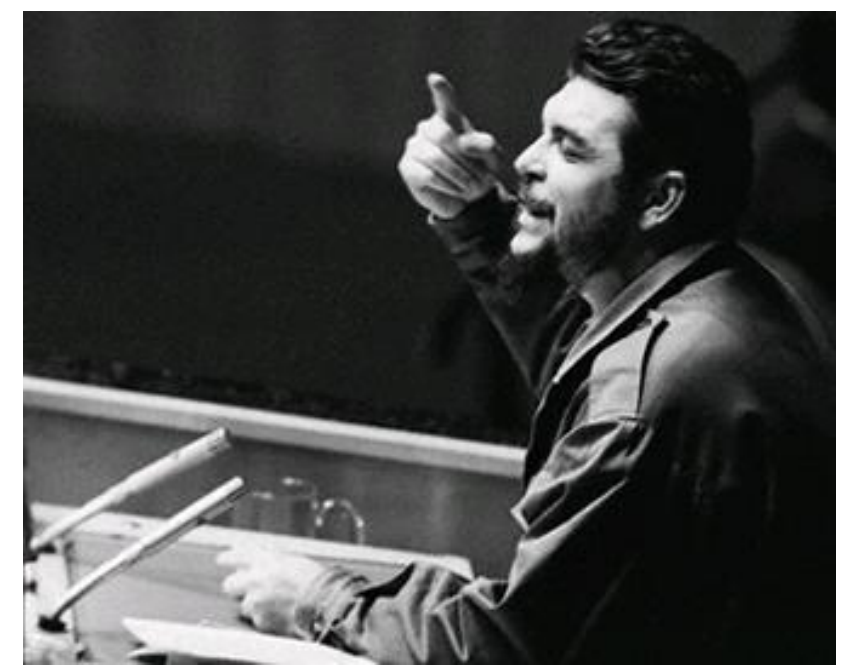

Figure 7. Che Guevara.

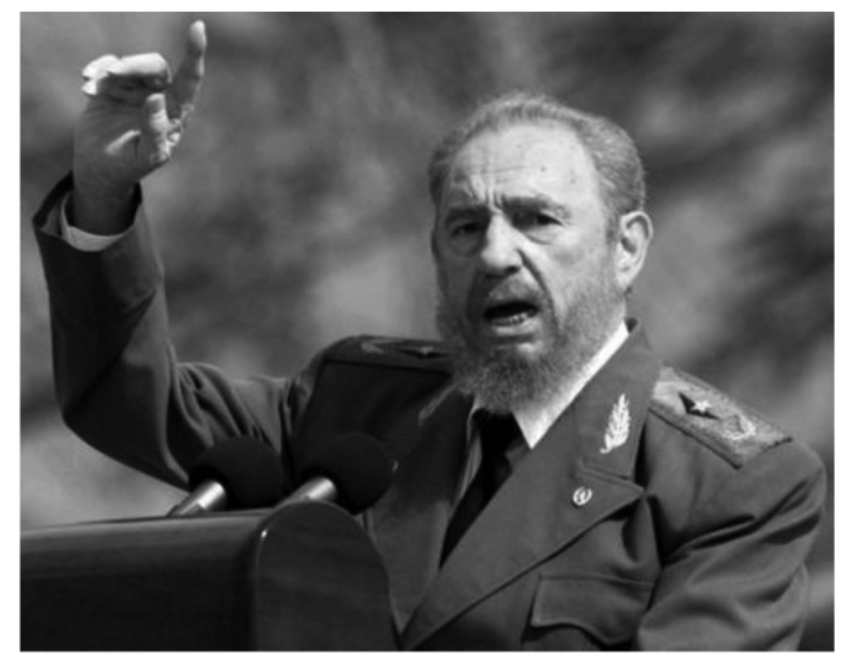

Figure 8. Fidel Castro.

This description of Guadalupe Llori's performance on the political stage has focused so far on the question of how Guadalupe is "doing identity" (West and Zimmerman, 1987) through her body movement, clothes, use of symbols, and rhetoric. The performative dimension of her performances now needs to be considered by questioning the subversive and transformative power of "new" political subjects like Guadalupe Llori, a power that parties like Pachakutik claim for themselves. Because "the notion that identity is performative (and note that this does not imply voluntarism) lends itself to claims about doing gender differently... this provides opportunities for radically redoing gender" (Cream, 1995:39). What Cream claims along with Butler (1990) about gender identity is certainly also relevant for other identity constructions like political identity or ethnic identity. With regard to transformations of the 
political towards a more inclusive and participative mode, it needs to be asked to what extent "new" political subjects "redo" political subjectivity and concomitantly the imaginations about and constructions of the political. As the empirical examples suggest, there is no easy answer to this question. Guadalupe Llori's ambivalent identity performances are typical for many female and indigenous politicians. In their performances, "new" political subjects constantly negotiate between traditional imaginations about how to do politics and be a politician, and, at the same time, distance themselves from and subvert these same discursive imaginations. Whereas Guadalupe Llori challenges the masculinity of Ecuador's postcolonial political spaces through her presence, her jewelry, and her rhetoric on the importance of her family and her love for her people, she reproduces the stereotype of a masculine politician by imitating masculine body movements, gestures and rhetoric. The same can be said with regard to the discursive imaginations of politics as "white people's business". Guadalupe challenges these imaginations through the use of indigenous symbols and rhetoric but she still clearly reproduces the whiteness of the political sphere by emphasizing her own whiteness in her campaign poster.

\section{Closing credits}

Visual ethnographies have been advocated here as a productive methodology to redeem the theoretical ambition of performative geographies. I have argued along with Rose (2011) that in order to conform to the theoretical assumption that performances are always linked to performativity (Gregson and Rose, 2000), the collected visual data needs to be analyzed against the backdrop of the visual representation of hegemonic imaginaries. Such a visual ethnography of performativity combines the strength of visual and ethnographic methodologies to capture both performances and the performative discourses framing them. Performative geographies can benefit from insights gained in sociology and visual anthropology, both of which have a long tradition of focusing on the body as a rich source of visual data. The suggested visual ethnography of performativity integrates these insights into human geography and demonstrates that visual methodologies are a productive way to capture and analyze nonlinguistic, embodied performances. Visual ethnographies in this sense are an appropriate methodology for geographies of embodiment (Harrison, 2000), affect/emotion (Pile, 2009) and everyday practices (Simonsen, 2007) that are interested in the way spatialities are brought into being through nonlinguistic practices, such as feelings, body movements, nonverbal interactions, clothing, and symbols.

Performative geographers aim to understand the way the observed performances are embedded in performativity, the discursive framing that enables and disciplines performances. To meet this aim, a visual ethnography of performativity needs to reveal a profound understanding of the way hegemonic discourses around, for example, femininity or whiteness are visually represented. To identify and analyse hegemonic discursive imaginaries, ethnographic methodologies offer great potential because they focus on an emic understanding of social life and long-term embeddedness in a research context. Hence, visual ethnographies that take into account the discursive framing of observed data appear to be a promising methodology for geographic research seeking to bring together practices and discourses (Müller, 2008) in order to develop more nuanced and vivid accounts of social life.

The empirical example was aimed at showing how the combination of different visual, ethnographic and text-based methods applied in this research project offer a way to capture the ambivalence in the "new" political subjects' identity performances and situate them within hegemonic discourses that define the political as masculine and white. Transformation processes such as the one described in the case of Ecuador's local spaces of politics frequently consist of slight slippages and variations of the hegemonic scripts. To identify and interpret these slight embodied slippages, such as the use of indigenous clothing or feminine or indigenous ways of performing political subjectivity through body language, a visual ethnography of performativity as developed in this paper is especially well suited. The particular strength of visual ethnography lies in capturing "seemingly unremarkable signs of everyday life" (Spencer, 2011:47) that are easily overlooked when one is taking ethnographic notes and absorbed by the event itself (see also Frers in this issue). Visual note-taking offers the possibility of examining past activities as "formerly present", immersing oneself again in the event but focusing on small hints and deviations from hegemonic ways of performing political subjectivity and spatiality.

To sum up, I would like to highlight that a visual ethnography of performativity as developed in this paper not only serves to capture the embodied performances that performative geographies are concerned with, but also highlights the performative aspect of any research process (Gregson and Rose, 2000; Pratt, 2000). It does so by making the gaze of the researcher more explicit (Kindon, 2003:145) than in conventional ethnographic research. Visual ethnography, by allowing the researcher and participants to discuss visual data together, also offers the opportunity to "see together [with the research participants] without claiming to be another" (Haraway, 1991:193) and produce in a collaborative research process a "negotiated version of reality" (Pink, 2001:24). 


\section{Sources}

Video 1: Pachakutik's electoral march, candidatos con la bandera, own research video.

Video 2: Electoral speech of Guadalupe Llori, own research video.

Video 3: Performance of Guadalupe Llori at the Oslo Freedom Forum 2010, http://www.youtube.com/watch?v= upjxt809Uic.

Link for all videos: http://youtu.be/KNflPx3ZsHs.

Figure 1: Electoral march, own research photo.

Figure 2: Emma waving, own research photo.

Figure 3: Constituents, own research photo.

Figure 4: Guadalupe Llori on the stage, own research photo.

Figure 5: Guadalupe Llori's campaign poster, own research photo.

Figure 6: Guadalupe Llori, own research photo.

Figure 7: Che Guevara, http://randomfactsoftheday.com/ 2009/12/11/december-11-2009/.

Figure 8: Fidel Castro, http://www.vorwaerts.ch/tag/ fidel-castro/.

All Internet links accessed 15 December 2011.

\section{References}

Butler, J.: Gender Trouble: Feminism and the Subversion of Identity, New York, Routledge, 1990.

Butler, J.: Bodies That Matter: On the Discursive Limits of "Sex", New York, London, Routledge, 1993.

Byron, M.: Using Audio-Visual Aids in Geography Research: Questions of Access and Responsibility, Area, 4, 379-385, 1993.

Castañeda, J.: Latin America's Left Turn, Foreign Aff., 3, 28-42, 2006.

Collier, J. and Collier, M.: Visual Anthropology: Photography as a Research Method, Albuquerque, NM, University of New Mexico Press, 1986.

Crang, M.: Qualitative Methods: The New Orthodoxy?, Prog. Hum. Geog., 5, 647-655, 2002.

Cream, J.: Re-Solving Riddles: The Sexed Body, in: Mapping Desire, edited by: Bell, D. and Valentine, G., London, 31-40, 1995.

Dirksmeier, P. and Helbrecht, I.: Time, Non-Representational Theory and the "Performative Turn" - Towards a New Methodology in Qualitative Social Research, Forum Qualitative Social Research, 2, 2008.

El Guindi, F.: Visual Anthropology: Essential Method and Theory, Plymouth, Altamira Press, 2004.

Emmison, M. and Smith, P.: Researching the Visual, London, Sage Publications Ltd., 2000.

Garrett, B. L.: Videographic Geographies: Using Digital Video for Geographic Research, Prog. Hum. Geog., 4, 521-541, 2011.

Geertz, C.: The Interpretation of Cultures, New York, Basic Books, 1973.

Gregson, N. and Rose, G.: Taking Butler Elsewhere: Performativities, Spatialities and Subjectivities, Environ. Plann. D, 4, 433452, 2000.

Haraway, D.: Simians, Cyborgs and Women: The Reinvention of Nature, London, Free Association Books, 1991.
Harrison, P.: Making Sense: Embodiment and the Sensibilities of the Everyday, Environ. Plann. D, 4, 497-517, 2000.

Herbert, S.: For Ethnography, Prog. Hum. Geog., 4, 550-568, 2000.

Kindon, S.: Participatory Video in Geographic Research: A Feminist Practice of Looking?, Area, 2, 142-153, 2003.

Kofman, E.: Feminist Transformations of Political Geography, in: The Sage Handbook of Political Geography, edited by: Cox, K., Low, M., and Robinson, J., London, 73-86, 2008.

Latham, A.: Research, Performance, and Doing Human Geography: Some Reflections on the Diary-Photograph, Diary-Interview Method, Environ. Plann. A, 11, 1993-2017, 2003.

Law, J. and Urry, J.: Enacting the Social, Econ. Soc., 3, 390-410, 2004.

Lorimer, J.: Moving Image Methodologies for More-Than-Human Geographies, Cult. Geogr., 2, 237-258, 2010.

Mead, M.: Visual Anthropology in a Discipline of Words, in: Principles of Visual Anthropology, edited by: Hockings, P., Berlin, New York, 3-10, 2003.

Megoran, N.: For Ethnography in Political Geography: Experiencing and Re-Imagining Ferghana Valley Boundary Closures, Polit. Geogr., 6, 622-640, 2006.

Morton, F.: Performing Ethnography: Irish Traditional Music Sessions and New Methodological Spaces, Soc. Cult. Geogr., 5, 661-676, 2005.

Mouffe, C.: On the Political, New York, Routledge, 2005.

Müller, M.: Reconsidering the Concept of Discourse for the Field of Critical Geopolitics: Towards Discourse as Language and Practice, Polit. Geogr., 3, 322-338, 2008.

Nash, C.: Performativity in Practice: Some Recent Work in Cultural Geography, Prog. Hum. Geog., 4, 653-664, 2000.

O’Neill, M., Giddens, S., Breatnach, P., Bagley, C., Bourne, D., and Judge, T.: Renewed Methodologies for Social Research: EthnoMimesis as Performative Praxis, Sociol. Rev., 50, 69-88, 2002.

Pile, S.: Emotions and Affect in Recent Human Geography, Trans. Inst. Br. Geogr. N. S., 1, 5-20, 2009.

Pink, S.: Doing Visual Ethnography: Images, Media and Representation in Research, London, Sage, 2001.

Pink, S.: Mobilising Visual Ethnography: Making Routes, Making Place and Making Images, Forum Qualitative Social Research, 9, 36, 2008.

Pratt, G.: Research Performances, Environ. Plann. D, 5, 639-651, 2000.

Rose, G.: Visual Methodologies: An Introduction to Researching with Visual Materials, London, Sage Publications, 2011.

Said, E.: Orientalism, New York, Vintage books, 1978.

Simonsen, K.: Practice, Spatiality and Embodied Emotions: An Outline of a Geography of Practice, Human Affairs, 17, 168-181, 2007.

Simpson, P.: "So, as You Can See ...”: Some Reflections on the Utility of Video Methodologies in the Study of Embodied Practices, Area, 3, 343-352, 2011.

Spencer, S.: Visual Research Methods in the Social Sciences, London, Routledge, 2011.

Sturken, M. and Cartwright, L.: Practices of Looking: An Introduction to Visual Culture, Oxford, Oxford University Press, 2009.

West, C. and Zimmerman, D.: Doing Gender, Gender Soc., 2, 125$151,1987$.

Young, L. and Barrett, H.: Adapting Visual Methods: Action Research with Kampala Street Children, Area, 2, 141-152, 2001. 